\title{
MOLECULAR DIFFERENTIATION BETWEEN SALMONELLA ENTERICA SUBSP ENTERICA SEROVAR PULLORUM AND SALMONELLA ENTERICA SUBSP ENTERICA SEROVAR GALLINARUM
}

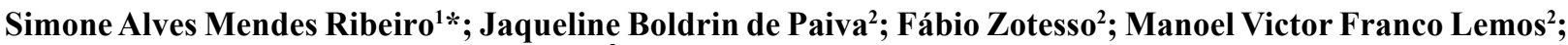 \\ Ângelo Berchieri Júnior ${ }^{2}$
}

${ }^{1}$ Laboratório Nacional Agropecuário, Ministério da Agricultura, Pecuária e Abastecimento, Campinas, SP, Brasil; ${ }^{2}$ Universidade Estadual Paulista, Faculdade de Ciências Agrárias e Veterinárias, Jaboticabal, SP, Brasil

Submitted: September 01, 2007; Returned to authors for corrections: March 03, 2008; Approved: February 15, 2009.

\begin{abstract}
S. Pullorum (SP) and $S$. Gallinarum (SG) are very similar. They are the agents of pullorum disease and fowl typhoid, respectively, and the two diseases are responsible for economic losses in poultry production. Although SP and SG are difficult to be differentiated in routine laboratory procedures, the ability to metabolize ornithine is a biochemical test that may be used to achieve this aim. While SP is able to decarboxylate this amino acid, SG is not. However, the isolation of strains showing atypical biochemical behavior has made this differentiation difficult. One of the genes associated with the metabolization of the amino acid ornithine is called $s p e \mathrm{C}$, and is found in both serovars. The analysis of $21 \mathrm{SP}$ and $15 \mathrm{SG}$ strains by means of PCR did not enable the differentiation of the two serovars, because fragments produced were identical. However, after enzymatic treatment with restriction enzyme Eco RI, the band pattern of each serovar showed to be different, even in samples of atypical biochemical behavior. This fact enabled the standardization of the technique for a quick and safe differentiation of serovars Pullorum and Gallinarum.
\end{abstract}

Keywords: Salmonella Pullorum, Salmonella Gallinarum, differentiation, PCR

\section{INTRODUCTION}

Salmonelloses are among the main infections affecting commercial poultry. They are responsible for direct and indirect losses to poultry production, besides their public health importance $(1,3)$. These bacteria infect poultry and may lead to pullorum disease, caused by Salmonella Pullorum (SP); fowl typhoid, caused by Salmonella Gallinarum (SG) and fowl paratyphoid, caused by any other salmonella but these ones (2).

Serovars Pullorum and Gallinarum are characterized as Salmonella enterica subsp enterica, group D (somatic antigens 1,9 and 12) and show antigenic and biochemical similarities. Both do not show flagella and grow slowly in culture media, different from the other salmonellas (2).
Although pullorum disease affects birds at any age, mortality rates are higher in young animals. Animals that survive may become carriers, may not meet expected animal production parameters and may produce contaminated eggs. The history of the disease and the development of industrial poultry breeding are mingled; artificial incubation of eggs was highly influenced by the occurrence of the disease, because it led to high mortality and culling rates among chicks. As eggs of different origins were incubated together, the agent of pullorum disease was transferred to other birds of commercial interest. In Brazil, there were several pullorum disease outbreaks in the 1980s and 1990s, even involving the occurrence of a strain of atypical biochemical behavior $(2,15)$.

Although fowl typhoid is caused by Salmonella very similar to the pullorum disease agent, its host-parasite relationship

*Corresponding Author. Mailing address: LANAGRO-SP, Campinas. Phone: (19) 3269-9822 and 3252-0155, Fax: (19) 3252-4835. E-mail: simone.ribeiro@agricultura.gov.br 
with the bird is markedly different. $S$. Gallinarum is highly pathogenic, capable of causing systemic infection and may affect birds of any age. However, its occurrence is more common among adult birds. Mortality caused by fowl typhoid may reach 40$80 \%$ of the flock. Fowl typhoid was initially described in England, at the end of the $19^{\text {th }}$ century, and it is considered to be a disease of developing countries (14). In Brazil, it was diagnosed in laying poultry facilities, but it may also affect adult breeding birds used in the production of egg-laying or meat chicks. According to data from the Laboratório de Patógenos Entéricos [Enteric Pathogens Laboratory] at Instituto Adolfo Lutz (São Paulo Brazil), among the 372 Salmonella samples identified in poultry breeding facilities from 1991 to 1995, 21 strains were $S$. Pullorum and 35 were $S$. Gallinarum $(2,10,15)$.

These two salmonellas are very similar in relation to antigenic and biochemical characteristics, but some tests have been used to differentiate between them, such as glucose, maltose and dulcitol fermentation, as well as utilization of d-tartrate, mucate, cellobiose, salicine and gelatin. According to TRABULSI \& EDWARDS (17), the ability or inability to assimilate ornithine would be the main biochemical test enabling the differentiation between SP and SG. However, the isolation of strains showing atypical biochemical behavior in this test makes it difficult to separate them $(4,14)$.

As early as 1935, NOBREGA (9) mentioned the difficulty in differentiating between $S$. Pullorum and $S$. Gallinarum only considering the biochemical and serological characteristics these strains. Although LANGENEGGER et al. (6) just observed the occurrence of strains showing typical biochemical and serological reactions, they mentioned the occurrence of atypical strains, with characteristics different from those observed in standard bacteria.

The differentiation between these two salmonellas is very important both in an epidemiological standpoint and in relation to control programs, once sanitary measures to be adopted would be different (14).

Kauffmann-White scheme (12) enables the classification of the genus Salmonella in more than 2,500 serovars using the combination of flagellar and somatic antigens. However, the differentiation between SP and SG is still not possible, once they belong to the same serogroup (1,9,12:-:-) and they do not have flagella. Because of these difficulties, alternative measures were developed, such as the use of molecular methods (13).

OLSEN et al. (11) analyzed SP and SG strains using molecular typing methods and reported their extreme similarity in terms of chromosome constitution. The genetic component that could be used in the differentiation between SP and SG would be genes related to ornithine assimilation (speC and $s p e \mathrm{~F}$ ), once the expression is different in the two serovars.

CUNNINGHAM-RUNDLES \& MAAS (5) observed mutant Escherichia coli colonies that did not grow adequately because they lacked ornithine decarboxylase (ODC) synthesis, determined by the gene speC. The same authors demonstrated that supplementation with putrescine or spermidine enabled normal growth.

Putrescine is an amine of living cells that has an important role as a precursor of spermidine. These two substances are related to cell growth and its regulation. Except in certain mutants, all organisms studied were able to synthesize putrescine, mostly by means of an enzyme called ornithine decarboxylase, which converts ornithine into putrescine (17).

The genes speC and speF, related to ornithine descarboxylation, are present both in SP and SG. It size are similar in serotypes Pullorum, Gallinarum, Typhimurium and different in S. Typhi. In SP, the genes are expressed and the bacterium is positive for ornithine; in SG, the genes are not expressed and ornithine results are negative $(4,7,16)$. Although this is the standard result expected, the occurrence of atypical reactions both in SP and SG makes it difficult to differentiate between these serovars.

Although genes speC and speF, are similar in SP and SG, it could show differences in relation to the action of restriction enzymes $(8,14)$.

\section{MATERIALS AND METHODS}

\section{Bacterial strains}

Strains used were obtained by the Laboratório Nacional Agropecuário (LANAGRO-SP) in reference centers in Brazil. Strains kept and/or isolated in the poultry pathology laboratory at FCAV/UNESP - Jaboticabal were also used. These strains came from Brazilian commercial poultry flocks and two of them came from the ATCC (American Type Collection Culture). Strains were previously identified in Fundação Oswaldo Cruz (FIOCRUZ-RJ) and Instituto Adolfo Lutz (IAL-SP), based on biochemical behavior and antigenic tests using serum antisomatic and flagelar antigens of Salmonella. Thirty six Salmonella samples kept in nutritive agar (DIFCO -213000) were used (21 S. Pullorum and $15 \mathrm{~S}$. Gallinarum, including strains showing atypical biochemical behavior in relation to ornithine).

The biochemical characteristics of all strains were tested for: urease, indole, $\mathrm{H}_{2} \mathrm{~S} / \mathrm{TSI}$, motility, sucrose, glucose, gás, dulcitol, maltose, mucate, salicin, cellobiose, lysine, ornithine, d-tartrate, Jordan tartrate, gelatinase, citrate e malonate.

SP and SG samples were cultured in LB broth (Luria Bertani - Invitrogen $12780-052$ ), overnight at $37^{\circ} \mathrm{C}$, under stirring. After that, samples were cultured in Petri dishes containing LB Agar and were incubated in the same conditions. A colony was lightly touched and directly immersed in a $1.5 \mathrm{~mL}$ eppendorf tube containing the PCR reagents.

\section{Primers and PCR conditions}

The primers for $\mathrm{PCR}$ amplification of speC and speF genes were based on previously described sequences (8). A forward 
primer, speC-1 (5'- GAAATC AAT GAA TAT TGC CG -3') and a reverse primer, speC-4 (5'-ATC GGC ATC GGT CTC GCT ATA TA-3'); a forward primer, speF-1 (5'- TTA GCC GTC ATT GCC CGGATT -3') and a reverse primer, speF-4 (5'-ACG AGG TTT AAT GAC GTA GC -3') were used. Amplification reaction mixtures contained $30 \mu \mathrm{L}$ X-mix $\left(916 \mu \mathrm{L} \mathrm{H}_{2} \mathrm{O}\right.$ milli-Q, $120 \mu \mathrm{L} 10 \mathrm{X}$ buffer, $120 \mu \mathrm{L}$ dNTP $(2 \mathrm{mM}), 36 \mu \mathrm{L} \mathrm{MgCl}) ; 0,5 \mu \mathrm{L}$ of each primer $1 \mathrm{e} 4(s p e \mathrm{C}$ or $s p e \mathrm{~F})$ and $0,4 \mu \mathrm{L}$ taq DNA polymerase (Invitroven 10342-020). The cycling parameters were $92^{\circ} \mathrm{C}$ for 3 min, followed by 24 cycles including denaturation at $92^{\circ} \mathrm{C}$ for 20seg, annealing at $50^{\circ} \mathrm{C}$ for $1 \mathrm{~min}$, extension at $72^{\circ} \mathrm{C}$ for $3 \mathrm{~min}$, and a final extension cycle of $72^{\circ} \mathrm{C}$ for $5 \mathrm{~min}$. The amplification products were observed by electrophoresis on $1 \%$ agarose gel and the size of the products was analyzed in comparison to a $1 \mathrm{~Kb}$ ladder M.W. size marker (GIBCO) after ethidium bromide staining.

\section{Restriction enzyme - Eco RI, Xba I and Sal I}

Five microliters of PCR product was added to $1 \mu \mathrm{L}$ of $10 \mathrm{X}$ reaction buffer, $1 \mu \mathrm{L}$ of enzyme [Eco R I (Invitrogen 15202-013) or Sal I (Invitrogen 15217-011) or Xba I (Invitrogen 15226-012)] and $3 \mu \mathrm{L}$ of DW and incubated at $37^{\circ} \mathrm{C}$ for $1: 30 \mathrm{~h}$. The products were analyzed by the same conditions written above.

\section{RESULTS}

\section{Amplification of the spec and spe F genes}

In this study, fragments of both genes was successfully amplified from all 21 strains of $S$. Pullorum and 15 of $S$. Gallinarum analyzed (Fig. 1).

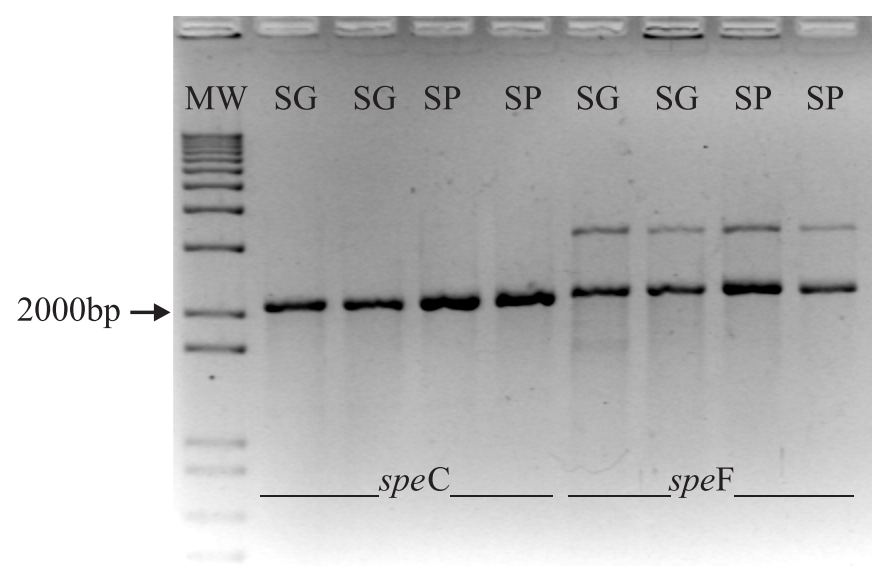

Figure 1. Eletrophoretic analysis of genes speC and $s p e \mathrm{~F}$. Lane 1: Molecular weight marker - 1Kb; lines 2, 3, 6, 7 (SG ATCC); lanes 4, 5, 8, 9 (SP ATCC); lines 2-5 (gene speC) and lines 6-9 (gene speF).

\section{Differentiation of $S$. Pullorum from $S$. Gallinarum}

In this study, strains of $S$. Pullorum and $S$. Gallinarum were analyzed after treatment with restriction enzymes Eco RI, $X b a$ I and $\mathrm{Sal}$ I. Differences in the banding pattern of serovars were noted after PCR amplification and treatment with both Eco RI and $X b a$ I. In the Fig. 2, S. Pullorum showed one band and S. Gallinarum showed none band after PCR amplification and treatment with Eco RI. The enzyme $S a l$ I not differentiated the two serovars because of the identical bands observed.

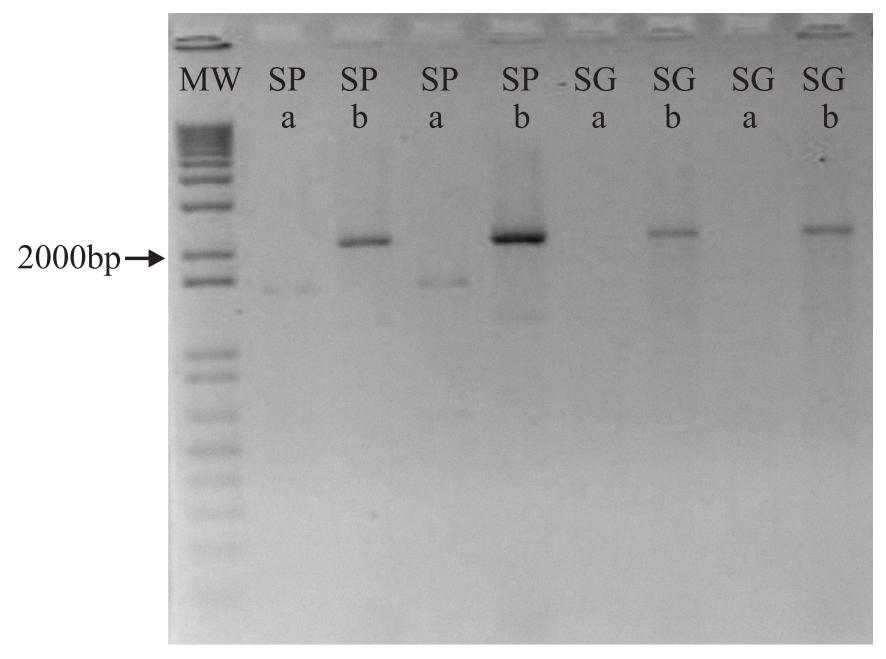

Figure 2. Eletrophoresis on agarose gel of gene speC after treatment with enzyme Eco RI showing: Molecular Weight marker, $1 \mathrm{~Kb}$ DNA ladder (lane 1); the reaction specific for $\mathrm{S}$. Pullorum (lines 2-3 for strain SP ATCC and 4-5 for strain SP 449/ 87) and specific for S. Gallinarum (lines 6-7 for strain SG ATCC and 8-9 for strain SG FIOCRUZ 31). The letter "a" in the gel refer the strain after enzymatic treatment and the letter "b" refer the PCR amplification.

\section{DISCUSSION}

$S$. Pullorum and $S$. Gallinarum are very similar in relation to their antigenic and biochemical characteristics, and some biochemical tests have been used in order to differentiate between them, such as ability to metabolize ornithine (16). As this characteristic is also found in atypical strains, the separation between the two serovars have been difficult $(4,14)$, a fact that have motivated the use of molecular methods.

Genes speC and speF, related to ornithine metabolization, are very similar in serovars Pullorum, Gallinarum and Typhimurium. These genes have already been sequenced in the latter strain (8). In the present study, the amplification of the two genes produced identical bands, both in SP and SG. 
However, the comparison with the results by McClelland et al. (2001) showed that there was unspecific amplification of gene $s p e \mathrm{~F}$, leading to the production of a fragment greater than was expected. Because of this, the gene was excluded from the later stages of the study.

Even with similar size in the two serovars, it is possible that the use of restriction enzymes would produce different fragments of gene speC (14). During the standardization of the methodology, this gene was amplified and the PCR product was tested with enzymes Eco RI, Xba I and Sal I with later analysis of the fragments. The use of enzyme $\mathrm{Sal}$ I was not able to differentiate between serovars Pullorum and Gallinarum. On the other hand, enzymes $E c o$ RI and $X b a$ I showed similar results. Due to the cost of these reagents, the enzyme Eco RI was preferred.

The amplification of gene speC and the treatment with enzyme Eco RI in SP strains enabled the visualization of one only band in electrophoresis. The same methodology in SG samples did not produce any band (Table 1).

Table 1. Results of biochemical analysis (ornithine), amplification of genes ( $s p e \mathrm{C}$ and $s p e \mathrm{~F}$ ) and treatment of enzymes (Sal I, Xba I and Eco RI).

\begin{tabular}{|c|c|c|c|c|c|}
\hline Strains & ornithine & $\begin{array}{l}\text { PCR amplification } \\
\text { (gene speC) }\end{array}$ & $\begin{array}{l}\text { PCR amplification } \\
\text { (gene spe } \mathrm{F} \text { ) }\end{array}$ & Enzyme Sal I & Enzyme $X b a \mathrm{I}$ \\
\hline SGFIOCRUZ31 & $(-)$ & + & + & no band & no band \\
\hline SGFIOCRUZ32 & $(-)$ & + & + & no band & no band \\
\hline SGFIOCRUZ33 & $(-)$ & + & + & no band & no band \\
\hline SGFIOCRUZ34 & $(-)$ & + & + & no band & no band \\
\hline SGFIOCRUZ35 & $(-)$ & + & + & no band & no band \\
\hline SGFIOCRUZ36 & $(-)$ & + & + & no band & no band \\
\hline SGLANAGRO 10 & $(-)$ & + & + & no band & no band \\
\hline SGLANAGRO 15 & $(-)$ & + & + & no band & no band \\
\hline SGLANAGRO 188-1C & $(-)$ & + & + & no band & no band \\
\hline SGLANAGRO 188-2 & $(-)$ & + & + & no band & no band \\
\hline SGUNESP HAKIM LEBANM & $(-)$ & + & + & no band & no band \\
\hline SGUNESP 256/87 & $(-)$ & + & + & no band & no band \\
\hline SGUNESP 291/90 & $(-)$ & + & + & no band & no band \\
\hline SGUNESP 292/90 & $(-)$ & + & + & no band & no band \\
\hline SGUNESP 293/90 & $(-)$ & + & + & no band & no band \\
\hline SGUNESP 297/91 & $(-)$ & + & + & no band & no band \\
\hline SGUNESP 372 GREEK & $(-)$ & + & + & no band & no band \\
\hline SGUNESP 5441-b & $(-)$ & + & + & no band & no band \\
\hline SG UNESP 72-805 NANABI & $(-)$ & + & + & no band & no band \\
\hline SGUNESP 7285-b & $(-)$ & + & + & no band & no band \\
\hline SGLANAGROATCC & $(-)$ & + & + & no band & no band \\
\hline SP $449 / 87$ & $(-)$ & + & + & no band & no band \\
\hline SP FIOCRUZ 1 & $(-)$ & + & + & no band & no band \\
\hline SPFIOCRUZ2 & $(-)$ & + & + & no band & no band \\
\hline SP FIOCRUZ3 & $(-)$ & + & + & no band & no band \\
\hline SP FIOCRUZ 4 & $(-)$ & + & + & no band & no band \\
\hline SP FIOCRUZ 5 & $(-)$ & + & + & no band & no band \\
\hline SP FIOCRUZ 6 & $(-)$ & + & + & no band & no band \\
\hline SP FIOCRUZ 7 & $(-)$ & + & + & no band & no band \\
\hline SP LANAGRO 11 & $(-)$ & + & + & no band & no band \\
\hline SPLANAGRO 335-26 & $(-)$ & + & + & no band & no band \\
\hline SPLANAGRO 337-28 & $(-)$ & + & + & no band & no band \\
\hline SPUNESP 21 & $(-)$ & + & + & no band & no band \\
\hline SPLANAGRO ATCC & $(-)$ & + & + & no band & no band \\
\hline
\end{tabular}

$(*+)$ and $\left(*^{-}\right)=$atypical strains in biochemical analysis (ornithine). 
It was observed in the study of gene speC that enzymatic treatment with enzyme Eco RI may be applied to SP and SG differentiation, even when samples show atypical biochemical behavior in relation to ornithine metabolization.

\section{ACKNOWLEDGEMENT}

We thank LANAGRO-SP and FCAV-UNESP for providing strains of Pullorum and Gallinarum. This work was supported by the FCAV-UNESP.

\section{RESUMO}

\section{Diferenciação molecular entre Salmonella enterica subsp enterica serovar Pullorum e Salmonella enterica subsp enterica serovar Gallinarum}

A S. Pullorum (SP) é muito semelhante à S. Gallinarum (SG), agentes da Pulorose e Tifo aviário, respectivamente, sendo que as duas enfermidades são responsáveis por perdas econômicas no setor avícola. SP e SG são de difícil diferenciação em procedimento laboratorial rotineiro, mas uma prova bioquímica muito utilizada na distinção das duas refere-se à capacidade de assimilar o aminoácido ornitina: SP descarboxila este aminoácido enquanto SG não. No entanto, o isolamento de cepas com comportamento bioquímico atípico, tem dificultado tal diferenciação. Um dos genes relacionados à assimilação do aminoácido ornitina, denomina-se gene speC, o qual está presente nos dois sorovares. Analisando 21 amostras de SP e 15 de SG com a utilização da PCR não foi possível realizar a diferenciação dos dois sorovares pois os fragmentos gerados eram idênticos. Posteriormente, com o uso da técnica de tratamento enzimático com a enzima de restrição Eco RI, foi possível observar que o padrão de bandas gerado em cada sorovar era diferente, mesmo quando amostras que apresentavam comportamento bioquímico atípico eram analisadas. Tal fato permitiu a padronização da técnica para ser utilizada na diferenciação entre os sorovares Pullorum e Gallinarum de maneira rápida e segura.

Palavras-chave: Salmonella Pullorum, Salmonella Gallinarum, diferenciação, PCR

\section{REFERENCES}

1. Andreatti Filho, R.L.; Patrício, I.S. (2004). Biosseguridade da granja de frangos de corte. In: MENDES, A. A.; NÄÄS, I. A.; MACARI, M. Produção de Frangos de Corte. Campinas: FACTA, 169-177.

2. Berchieri Jr., A. (2000). Salmoneloses aviárias. In: Berchieri Jr, A., Macari, M. Doenças das aves. Facta, Campinas. 185-196.
3. Berchieri Jr., A.; Murphy, C.K.; Marston, K.; Barrow, P.A. (2001). Observations on the persistence and vertical transmission of Salmonella enterica serovars Pullorum and Gallinarum in chickens: effect of bacterial and host genetic background. Avian Pathol., v. 30, 229-239.

4. Christensen, J.P.; Olsen, J.E.; Hansen, H.C.; Bisgaard, M. (1992). Charaterization of Salmonella enterica serovar Gallinarum biovar gallianrum and pullorum by plasmid profiling and biochemical analysis. Avian Pathol., 21: 461-470.

5. Cunningham-Rundles, S.; Maas, W.K. (1975). Isolation, Characterization, and Mapping of Escherichia coli Mutants Blocked in the Synthesis of Ornithine Decarboxilase. J. Bacteriol. 791-799, 1975.

6. Langenegger, C.H.; Langenegger, J.; Araújo, L.M.G. (1982). Comportamento Bioquímico e Composição Antigênica de Culturas de Salmonella gallinarum e S. pullorum Isoladas no Brasil. Pesqui. Vet. Bras. 2(4): 149-154.

7. Li, J.; Smith, N.H.; Nelson, K.; Chichton, P.; Old, D.C.; Whittam, T.S.; Selander, R.K. (1993). Evolutionary origin and radiation of the avian-adapted non-motile salmonellae. J. Med. Microbiology. v. 38, 129-139.

8. McClelland, M.; Sanderson, K.E.; Spieth, J.; Clifton, S.W.; Latreille, P.; Courtney, L.; Porwollik, S.; Ali, J.; Dante, M.; Du, F.; Hou, S.; Layman, D.; Leonard, S.; Nguyen, C.; Scott, K.; Holmes, A.; Grewal, N.; Mulvaney, E.; Ryan, E.; Sim, H.; Florea, L.; Miller, W.; Stoneking, T.; Nhan, M.; Waterston, R.; Wilson, R.K. (2001). Complete genome sequence of Salmonella enterica serovar Typhimurium LT2. Nature. 25, 413(6858): 852-6

9. Nobrega, P. (1935). Diferenciação entre "S. pullorum", e "S. gallinarum". Arq. Inst. Biol. v. 6, 71-84.

10. Oliveira, G.H.; Fernandes, A.C.; Berchieri Jr, A. (2001). Estudo sobre a epidemiologia de Salmonella Gallinarum em aves de postura comercial. Rev. Bras. Cienc. Avic., Campinas: FACTA. Conferência APINCO de Ciência e Tecnologia Avícolas. Prêmio José Maria Lamas da Silva, supl. 3, 89 .

11. Olsen, J.E.; Skov, M.N.; Christensen, J.P.; Bisgaard, M. (1996). Genomic lineage of Salmonella enterica serotype Gallinarum. J. Med. Microbiol. v. 45, 413-418.

12. Poppoff, M.Y. (2001). Antigenic formulas of the Salmonella serovars, 8th ed. W.H.O. Collaborating Centre for Reference and Research on Salmonella. World Health Organ., Geneva, Switzerland.

13. Proux, K.; Humbert, F.; Jouy, E.; Houdayer, C.; Lalande, F.; Oger, A.; Salvat, G. (2002). Improvements required for the detection of Salmonella Pullorum and Gallinarum. Can. J. Vet. Res. 66: 151157.

14. Sambrook, J.; Russel, D.W. Molecular Cloning: A Laboratory Manual. Cold Spring Harbor Laboratory Press, Cold Spring Harbor, New York.

15. Shivaprasad, H.L. (1997). Pullorum disease and fowl typhoid. In: Calnek, B.W. et al. Diseases of poultry. Iowa State University Press, Ames, Iowa, USA, pp. 82-96.

16. Tavechio, A.T.; Fernandes, S.A.; Neves, B.C.; Dias, A.M.G.; Irino, K. (1996). Changing patterns of Salmonella serovars: Increase of Salmonella Enteritidis in São Paulo Brazil. Rev. Inst. Med. Trop. Sao Paulo, 38: 315-322.

17. Trabulsi, L.R.; Edwards, P.R. (1962). The differentiation of Salmonella Pullorum and Salmonella Gallinarum by biochemical methods. Cornell Vet. V. 52, 563-569.

18. Wright, J.M.; Boyle, S.M. (1982). Negative control of ornithine decarboxilase and arginine decarboxilase by adenosine-3' $: 5$ '-cyclic monophosphate in Escherichia coli. Mol. Gen. Genet. 186: 482487. 